\title{
The Efficacy of Chewing Gum in Postoperative lleus Management After Robot Assisted Laparoscopic Radical Prostatectomy: A Prospective Randomized Study
}

\author{
Robot Yardımlı Laparoskopik Radikal Prostatektomi Sonrası Oluşan \\ Fizyolojik İleus Yönetiminde Sakız Çiğnemenin Etkinliği
}

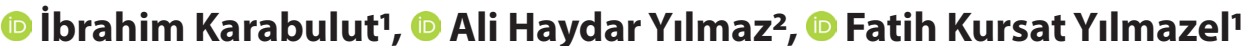

'Education and Research Hospital, Deparment of Urology, Erzurum, TURKEY

2Bilecik State Hospital, Department of Urology, Bilecik, TURKEY

\begin{abstract}
Aim: To examine the efficacy of chewing gum on bowel motility in the early postoperative period in patients with prostate cancer undergoing robot-assisted laparoscopic prostatectomy (RALP) we prepared this study.

Material and Method: Prior to the study, approval was obtained from the local ethics committee. A total of 67 patients were included in the study. The patients were randomly assigned to the control group (Group C) and two groups. Patients in the study environment were chewed gum from the postoperative eye. Intestinal function improvement was examined. The study was terminated at the first gas transition. This time interval has been recorded. Demographic photos, intraoperative parameters, surgical results were analyzed and compared. The first time of bowel movement, length of hospital stay, and surgical wound site pain and abdominal pain were recorded at the 12th and 24th hours postoperatively.

Results: The mean age of the patients in the study group was $60.56 \pm 6.07$ years, and that of the control group was $60.26 \pm 6.87$ years. At the end of the study, 23 patients in group $C$ and 25 patients in group $\mathrm{G}$ were evaluated. There was no significant difference in demographic data between the groups. No significant difference was observed between the two groups in the perioperative parameters. A significant statistical difference was found in favor of group $\mathrm{G}$ at the 24th and 36th hours of initial bowel movements, postoperative abdominal and wound pain.
\end{abstract}

Conclusions: This study indicated that chewing gum is also efficient in early solution of postoperative ileus.

Keywords: Chewing gum, prostate cancer, paralitic ileus, robotic surgery
Öz

Amaç: Major ürolojik cerrahi sonrası görülen ileus, hasta iyileşmesini geciktirebilir . Biz bu çalışmamızda kliniğimizde prostat kanseri nedeni ile robot yardımlı laparoskopik prostatektomi (RALP) uygulanan hastalarda postoperatif erken dönemde sakız çiğnemenin bağırsak hareketliliği üzerindeki etkinliğinin araştırı masını amaçladık.

Gereç ve Yöntem: Çalışma öncesi yerel etik kuruldan onam alındı. Çalışmaya toplam 67 hasta dahil edildi. Hastalar rastgele kontrol grubu (Grup C) ve çalışma grubu (Grup G) olarak iki gruba ayrıldı. Çalışma grubunda ki hastalara postoperatif dönemde sakız çiğnetildi. Bağırsak fonksiyon iyileşmesi incelendi. Çalışma ilk gaz geçişinde sonlandırıldı. Bu zaman aralığı kaydedildi. Demografik veriler, intraoperatif parametreler, cerrahi sonuçlar analiz edildi ve karşılaştırıldı. Ameliyat sonrası 12. ve 24. saatlerde barsak hareketinin ilk zamanı, hastanede kalış süresi ve cerrahi yara bölgesi ağrısı ve karın ağrısı kaydedildi.

Bulgular: Çalışma grubundaki hastaların yaş ortalaması $60,56 \pm 6,07$ yıl, kontrol grubundaki hastaların ise $60.26 \pm 6.87$ yıl olarak ölçüldü. Çalışmanın sonunda grup C de 23 hasta, grup G de 25 hasta değerlendirildi. Gruplar arasında demografik verilerde anlamlı fark yoktu. Perioperatif parametrelerde her iki grup arasında anlamlı bir fark gözlemlenmedi. Illk bağırsak hareketleri, postoperatif karın ve yara bölgesi ağrısı 24. ve 36. saatler de grup $\mathrm{G}$ lehine anlamlı derecede istatistiksel fark tespit edildi.

Sonuç: Bu çalışma sakız çiğnemenin postoperatif ileusun erken dönemde çözümlenmesinde etkili olduğunu göstermiştir.

Anahtar Kelimeler: Sakı, prostat kanseri, paralitik ileus, robotik cerrahi 


\section{INTRODUCTION}

Postoperative ileus (POI) was described by Livingston and Passaro as an uncomplicated ileus that developed after surgery and generally resolved spontaneously within 2-3 days. Postoperative ileus improves with the initiation of gastric motility after 24 to 48 hours and of colon motility after 48 to 72 hours. ${ }^{[1]}$ The ileus seen after major urological surgeries may cause nausea, vomiting and abdominal distension in patients, may delay patient recovery and cause additional problems. Its incidence in abdominal surgery varies between $17.4 \%$ and $24 \%{ }^{[2]} \mathrm{POI}$ is the most common minor postoperative complication that causes morbidity and delays in the length of hospital stay and leads to increasing economic burden on health system.$^{[3]}$ Early feeding, chewing gum, nasogastric intubation, epidural anesthesia and analgesia, early mobilization and physical therapy methods have been tried for early acquisition of bowel mobilization. ${ }^{[4-9]}$ However, these treatments could not come into routine use because of their limited clinical efficacy. ${ }^{[6]}$

In the treatment of localized prostate cancer, radical prostatectomy is an established treatment method that provides excellent cancer control. ${ }^{[10]}$ While the traditional method is open surgical approach, robot-assisted laparoscopic prostatectomy (RALP) has been widely used, especially in Europe and the United States for the last decade. ${ }^{[11,12]}$ When compared with open surgery, RALP offers advantages such as less blood loss and shorter operative time. ${ }^{[13]} \mathrm{POI}$ leads to morbidity after RALP in which abdominal approach is particularly preferred. There are several studies on the management of $\mathrm{POI}$ after major urological surgical procedures and the efficacy of gum is emphasized in these studies. ${ }^{[5,14,15]}$ However, our study will be the first in the literature since there is no study related to the efficacy of chewing gum on POI after isolated RALP in the literature.

In this study, we aimed to examine the efficacy of chewing gum on bowel motility in early postoperative period in patients undergoing RALP due to localized prostate cancer in a prospective and randomized design.

\section{MATERIAL AND METHOD}

The study was planned as a prospective randomized study between January 2018 and February 2019 and approval was obtained from the local ethics committee before the study. The details of the study were explained to the patients participating in the study and written consent was obtained. A total of 67 patients were included in the study. Patients with abdominal surgery and / or a history of radiotherapy treatment, have a history of any gastrointestinal disease and inflammatory bowel diseases were excluded from the study (Figure 1). Patients were randomized by assigning in order to either the chewing gum group or the control group.

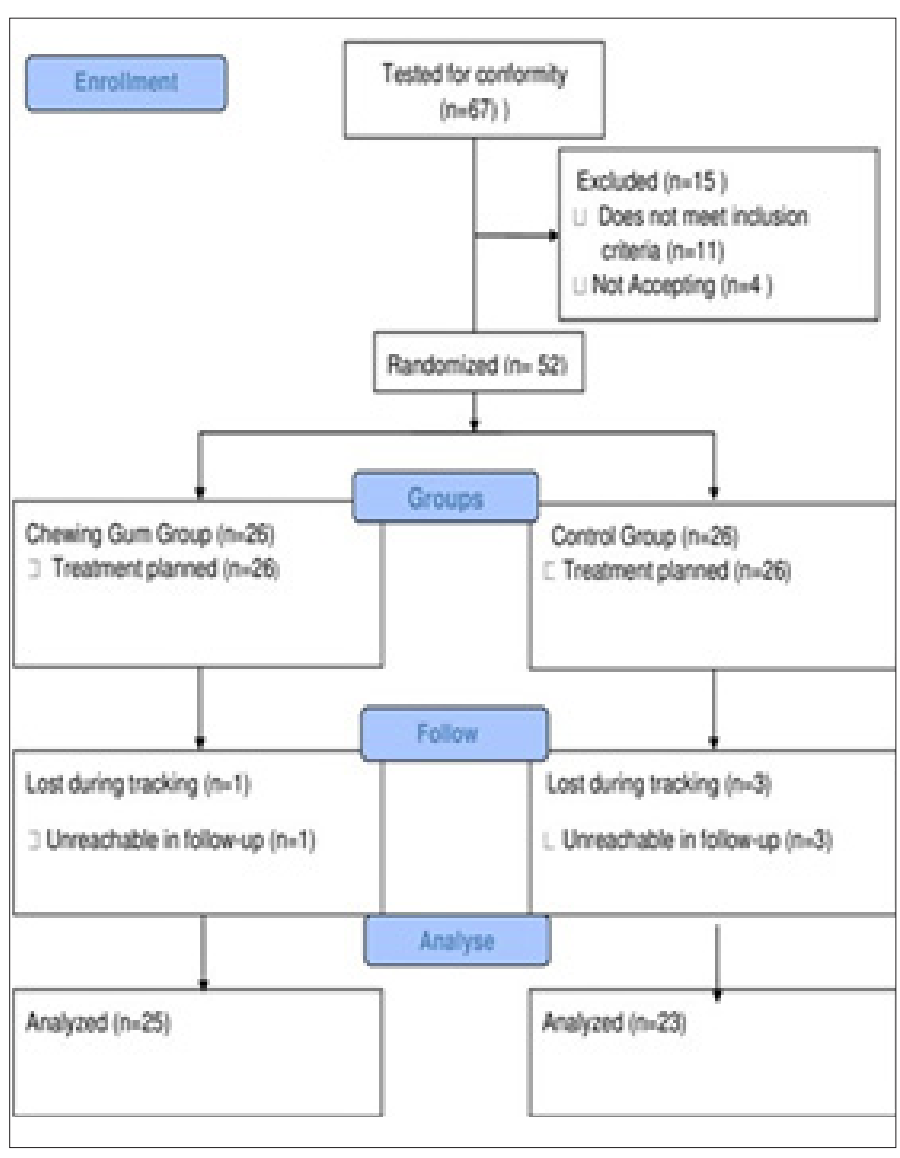

Figure 1. Flow chart diagram

Preoperatively, all patients were started on a clear aqueous diet one day before surgery, and mechanical bowel preparation was performed using Fleet Phospho-soda (CB Fleet Company. Lynchburg, VA). Preoperative oral antibiotics were not used. RALP procedure described by Menon was performed by the same surgical team in all patients participating in the study. ${ }^{[16]}$

In the postoperative period, the patients in the chewing gum group were chewed gum without sugar three times for 30 minutes at 8-hour intervals starting from the 12th postoperative hour. After surgery, the patient's awakening was determined as 0th hour. The same team was assigned to monitor bowel function improvement and possible bowel related conditions. Whether the patients in the study and control groups followed the instructions given or not was closely monitored and documented. The point where POI disappeared was accepted as the point where the first gas passage occurred, and the study was terminated at this point. The time from the 0th postoperative hour to the point of disappearance of POI was recorded. The same postoperative care was applied to the patients in both groups, except for additional chewing gum in patients in the study group. No orogastric or nasogastric catheter was placed in any patient during the operation. 
Demographic data including age, body mass index (BMI), American Society of Anesthesiologists (ASA) score, history of additional disease such as hypertension and diabetes mellitus etc. were recorded. Intraoperative parameters including anesthesia time, console time and estimated blood loss were analyzed and surgical results were compared. The first time of postoperative gas passage and bowel movement, length of hospital stay, and surgical wound site pain and abdominal pain intensity according to the Visual Analogue Scale (VAS) were recorded at the 12th 24th and 36th postoperative hours. All patients underwent general anesthesia. Patients were not given any drugs related to bowel motility. Epidural analgesia was not used in any patient.

Routine cystography was performed to check the recovery of the vesicoureteral anastomosis site on the 7th postoperative day after discharge of the patients and their catheters were removed.

\section{Statistical Analysis}

Multiple regression analysis was carried out to determine the association between independent variables (age, BMI, education level, gum chewing, anesthesia duration) and the post-operative measurement of VAS and gas discharge.

In the power analysis performed with postoperative intestinal gases variable, it was determined that in the $95 \%$ confidence interval and 0.05 significance level, power was 0.99 . This result indicates that the study sample is sufficient. The statistical data was analyzed by the IBM SPSS 20.0 software. The KolmogorovSmirnov test was used to evaluate the data distribution. Categorical data was compared between groups using the Pearson Chi-2 test. We used the Mann Whitney-U test to check differences among groups, at a significance level of $5 \%$ for normally distributed continuous variables. Descriptive statistics was expressed as a mean \pm SD.

Approval was optained from Erzurum Training and Research Hospital Clinical Research Ethics Committee with decision no and dated as 06-2018/01.

\section{RESULTS}

A total of 48 patients completed the study. At the end of the study, 23 patients in the control group and 25 patients in the chewing gum group were evaluated. The demographic and perioperative results of the control and chewing gum groups are shown in Table 1. There was no significant difference in age, BMI, ASA score between the control and chewing gum groups. No statistically significant difference was observed in total anesthesia time, console time and estimated blood loss (Table 1). When the first gas passage and bowel movements, visual analogue scores
(VAS) of postoperative abdominal and surgical wound site pain at the 24th and 36th hours were compared, a statistically significant difference was found in favor of the study group ( $p$ $<0.05$ ) (Table 2,3).When compared with the control group, it was observed that the median time to the gas passage was reduced in the chewing gum group (Table 4). Shorter hospital stay was observed in the patients of the study group, which was not statistically significant.

\begin{tabular}{|c|c|c|c|}
\hline & Group G (n:25) & Group C (n:23) & p \\
\hline Age (years) & $60.56 \pm 6.07$ & $60.26 \pm 6.87$ & $0.959 a$ \\
\hline BMI $\left(\mathrm{kg} / \mathrm{cm}^{2}\right)$ & $25.64 \pm 3.60$ & $26.22 \pm 3.13$ & $0.554 a$ \\
\hline ASA (I/II/III) & $3 / 19 / 3$ & $5 / 16 / 2$ & $0.646 \beta$ \\
\hline $\begin{array}{l}\text { Duration Time of Anesthesia } \\
\text { (min) }\end{array}$ & $182.76 \pm 8.48$ & $179 \pm 12.22$ & $0.121 a$ \\
\hline $\begin{array}{l}\text { Duration Time of } \\
\text { Hospitalisation (day) }\end{array}$ & $6.24 \pm 0.83$ & $6.65 \pm 0.57$ & $0.074 a$ \\
\hline Console Time (min) & $152.64 \pm 11,16$ & $150.78 \pm 10.64$ & $0.779 a$ \\
\hline $\begin{array}{l}\text { Concomitant Disease (DM/ } \\
\text { HT/DM+HT/COPD/none) }\end{array}$ & $4 / 5 / 1 / 3 / 12$ & $5 / 5 / 1 / 2 / 10$ & $0.982 \beta$ \\
\hline
\end{tabular}
Mann Whitney-U test between groups.

Table 2. The Comparison of VAS (Abdominal Pain) values between Group $\mathrm{G}$ and Group C

\begin{tabular}{lccc} 
& Group G (n:25) & Group C (n:23) & $\mathbf{P}$ \\
\hline VAS 12st hours & $8.32 \pm 0.98$ & $8.39 \pm 0.94$ & $0.682 a$ \\
VAS 24nd hours & $5.72 \pm 1.17$ & $7.17 \pm 0.77$ & $<0.001 \beta$ \\
VAS 36th hours & $4.32 \pm 0,98$ & $5.74 \pm 0.91$ & $<0.001 \beta$ \\
\hline $\begin{array}{l}\text { Values are expressed mean } \pm \text { standart deviation, VAS:Visual analog pain scale. a p }>0,05 \text { Mann } \\
\text { Whitney-U test between groups, } \\
\beta \text { p }<0,001 \text { Mann Whitney-U test between groups } \gamma p<0.05\end{array}$ \\
\hline
\end{tabular}

Table 3. The Comparison of VAS (Surgery Pain) values between Group G and GroupC

\begin{tabular}{|c|c|c|c|}
\hline & Group G (n:25) & Group C (n:23) & $\mathbf{p}$ \\
\hline VAS 12st hours & $8.68 \pm 0,62$ & $8.65 \pm 0,64$ & $0.854 a$ \\
\hline VAS 24nd hours & $5.68 \pm 1,10$ & $6.96 \pm 0,92$ & $<0.001 \beta$ \\
\hline VAS 36th hours & $4.16 \pm 0,85$ & $5.09 \pm 0,84$ & $0.001 \gamma$ \\
\hline \multicolumn{4}{|c|}{$\begin{array}{l}\text { Values are expressed mean } \pm \text { standart deviation, VAS:Visual analog pain scale, a } p>0,05 \text { Mann } \\
\text { Whitney-U test between groups, } \beta p<0,001 \text { Mann Whitney-U test between groups, } \gamma p<0.05 \text { Mann } \\
\text { Whitney-U test between groups. }\end{array}$} \\
\hline
\end{tabular}

Table 4. The Comparison of incidence of side effects between Group $\mathrm{G}$ and Group C

\begin{tabular}{lccc} 
& $\begin{array}{c}\text { Group G } \\
(\mathbf{n : 2 5 )}\end{array}$ & $\begin{array}{c}\text { Group C } \\
(\mathbf{n : 2 3 )}\end{array}$ & P \\
\hline Postoperative Intestinal Gases & $24.56 \pm 4,47$ & $33.96 \pm 4,09$ & $<0.001 \mathrm{a}$ \\
& $86.60 \pm 23.17$ & $83.91 \pm 18.21$ & $0.909 \beta$ \\
\hline Total Bleeding & \multicolumn{3}{l}{$\begin{array}{l}\text { Values are expressed mean } \pm \text { standart deviation or numbers a } p<0,001 \text { Mann Whitney-U test } \\
\text { between groups, } \\
\beta p>0,05 \text { Mann Whitney-U test between groups, } \gamma p>\gamma p>0,05\end{array}$ Chi-square test between group } \\
\hline
\end{tabular}


Complication rates were $13.8 \%$ in the control group while they were observed as $12 \%$ in the study group. In the control group, 2 (8.6\%) patients had fever in response to medical treatment and 1 (4.2\%) patients had prolonged ileus that did not require nasogastric catheter use. In the study group, 2 (8\%) patients had postoperative fever in response to medical treatment, and 1 (4\%) patient had anastomotic leakage in cystography taken at the end of the first week. On the absence of leakage in cystography taken on the 15th day, TU catheter of the patient with anastomotic leakage was removed. Education level of the patients were not different statistically (p:0.931).Regression analysis showed that gum chewing was independently associated decreased VAS score measured at the 24th and 36th hours post-operatively (Table 5,6,7).

\begin{tabular}{|c|c|c|c|}
\hline Independent variable & Coefficient & Standard Error & p value \\
\hline Age (years) & -0.037 & 0.024 & 0.131 \\
\hline BMI & 0.063 & 0.042 & 0.143 \\
\hline Gum chewing & -1.38 & 0.28 & $<0.001$ \\
\hline Anesthesia duration ( $\mathrm{min}$ ) & -0.005 & 0.015 & 0.739 \\
\hline Education (years) & 0.076 & 0.046 & 0.108 \\
\hline
\end{tabular}

$\begin{aligned} & \text { Table 6. Regression analysis of independent variables that affect the } \\
& \text { abdominal pain at the 36th hour post-operatively. }\end{aligned}$
\begin{tabular}{|lccc} 
Independent variable & Coefficient & Standard Error & p value \\
\hline Age (years) & -0.016 & 0.024 & 0.511 \\
BMI & 0.072 & 0.041 & 0.091 \\
Gum chewing & -1.30 & 0.29 & $<0.001$ \\
Anesthesia duration (min) & -0.003 & 0.014 & 0.816 \\
Education (years) & 0.029 & 0.045 & 0.529 \\
\hline BMI, body mass index & & & \\
\hline
\end{tabular}

$\begin{aligned} & \text { Table 7. Regression analysis of independent variables that affect the post- } \\
& \text { operative time elapsed until the gas discharge. }\end{aligned}$
\begin{tabular}{llll} 
Independent variable & Coefficient & Standard Error & p value \\
\hline Age (years) & -0.074 & 0.106 & 0.487 \\
BMI & 0.053 & 0.183 & 0.770 \\
Gum chewing & -9.51 & 1.235 & $<0.001$ \\
Anesthesia duration (min) & 0.056 & 0.064 & 0.384 \\
Education (years) & 0.469 & 0.199 & 0.023 \\
\hline BMI, body mass index & & &
\end{tabular}

\section{DISCUSSION}

Postoperative ileus is defined as short-term loss of intestinal contractions. The main responsible factor in this process is thought to be peritoneal irritation. ${ }^{[17]}$ Sympathetic activity plays an inhibitory role while parasympathetic activity plays an activator role on bowel movements. The digestive control is under the influence of the cephalic-vagal pathway, which has direct axonal extensions from the orofacial motor neurons of the vagal afferent stimulation pathway and this pathway has an inhibitory effect on sympathetic activity. ${ }^{[18]}$ In the postoperative period, sympathetic hyperactivity and increased plasma catecholamine levels are accused as the underlying cause of $\mathrm{POI}^{[19]}$ Chewing gum can play a regulatory role on gastrointestinal system hormones and movements by creating a false digestive mechanism. ${ }^{[14]}$ Accordingly, indirect vagal stimulation of smooth muscle fibers has been shown to increase blood plasma levels of some hormones (gastrin, neurotensin, pancreatic polypeptide and cholecystokinin). ${ }^{[2]}$ It is also known that chewing gum increases liver, pancreas, stomach and salivary gland secretions. ${ }^{[14]}$ Depending on these, the way that can be associated with gum is that increased saliva and cephalic phase increase gastric secretions. Increased secretions and jaw movements initiate the first step of the digestive process and cause the stomach to prepare itself for food. As a result of the contribution of all these factors, it was accepted that chewing gum is an efficient and reliable method for improving bowel function after surgery. ${ }^{[21,22] ~ I n ~ o u r ~}$ study, we found that the bowel functions of the patients in the chewing gum group improved in an early period which was statistically significant, when compared with the control group.

Postoperative ileus can cause pain and discomfort in patients. It is also associated with long hospital stay and increased health costs. ${ }^{[23,24]}$ Long hospital stay is an important clinical outcome. In 2002, Asso et al. ${ }^{[25]}$ first reported the efficacy of chewing gum. It is an important advantage that chewing gum leads to early excretion of gas and thus early feeding, so that reduced complications and early healing can be observed. ${ }^{[26,27]}$ The most important point here is the false digestive event caused by chewing gum and does not have any side effects. In our study, it was observed that the patients in the chewing gum group were discharged early in statistical terms.

In our study, abdominal VAS and surgical wound site VAS of the patients were also recorded unlike similar studies in the literature. As a result of the study, a statistically significant difference was found in abdominal and surgical wound site VAS scores in favour of the study group.

There are a few limitations of our study. The first bowel movements, the point where this study was terminated, may not be the most ideal point because it is dependent on the patients and may require patients who has high level of consciousness. The fact that the study was conducted with small groups and lack of blindness is seen as another weakness. Nonetheless, more comprehensive prospective studies are needed, which seem to be simple but prove the efficacy of the effective method. 


\section{CONCLUSION}

Robot-assisted laparoscopic prostatectomy is being applied with increasing frequency in the treatment of loacized prostate cancer in the decad. This situation increases the frequency of encountering postoperative complications. We are convinced that tasteless chewing gum will be effective in the early resolution of the ileus observed in these surgeries.

\section{ETHICAL DECLARATIONS}

Ethics Comittee Approval: The ethic approval was optained from Erzurum Training and Research Hospital Clinical Research Ethics Committee with decision no and dated as 06-2018/01.

Informed Consent: Written informed consent was obtained from all participants who participated in this study.

Status of Peer-review: Externally peer-reviewed.

Conflict of Interest Statement: The authors have no conflicts of interest to declare.

Financial Disclosure: The authors declared that this study has received no financial support.

Author Contributions: All of the authors declare that they have all participated in the design, execution, and analysis of the paper, and that they have approved the final version.

\section{REFERENCES}

1. Livingston EH, Passaro EP. Postoperative ileus. Dig Dis Sci 1990; 35.121-32.

2. Shibata Y, Toyoda S, Miyati M, et al. Patterns of intestinal motility recovery during the early stage f ollowing abdominal surgery: clinical and manometric study. World J Surg. 1997; 21: 806-809.

3. Lee $\mathrm{H}$, Cho CW, Yoon S, et al. Effect of sham feeding with gum chewing on postoperative ileus after liver transplantation - a randomized controlled trial. Clin Transplant 2016; 30: 1501-7.

4. Matros E, Rocha F, Zinner M, et al. Does gum chewing ameliorate postoperative ileus? Results of a prospective, randomized, placebo controlled trial. J Am Coll Surg 2006; 202: 773-8.

5. Choi H, Kang SH, Yoon DK, et al. Chewing gum has a stimulatory effect on bowel motility in patients after open or robotic radical cystectomy for bladder cancer: a prospective randomized comparative study. Urology 2011; 77: 884-90.

6. Asgeirsson T, El-Badawi KI, Mahmood A, et al. Postoperative ileus: it costs more than you expect. J Am Coll Surg 2010; 210: 228-31.

7. Noble EJ, Harris R, Hosie KB, et al. Gum chewing reduces postoperative ileus? A systematic review and meta-analysis. Int J Surg 2009; 7: 100-5.

8. Bisanz A, Palmer JL, Reddy S, et al. Characterizing postoperative paralytic ileus as evidence for future research and clinical practice. Gastroenterol Nurs 2007; 31: 336-44.
9. Holte $\mathrm{K}$, Kehlet $\mathrm{H}$. Postoperative ileus: a preventable event. $\mathrm{Br} \mathrm{J}$ Surg 2000; 87: 1480-93.

10. Heidenreich A, Bellmunt J, Bolla $M$ et al. EAU guidelines on prostate cancer. Part 1: screening, diagnosis and treatment of clinically localised disease. Eur Urol 2011; 59: 61-71.

11.Leow JJ, Chang SL, Meyer CP et al. Robot-assisted versus open radical prostatectomy: a contemporary analysis of an all-payer discharge database. Eur Urol 2016; 70: 837-45

12.Stolzenburg JU, Kyriazis I, Fahlenbrach C et al. National trends and differences in morbidity among surgical approaches for radical prostatectomy in Germany. World J Urol 2016; 34: 1515-20

13.Yaxley JW, Coughlin GD, Chambers SK et al. Robot-assisted laparoscopic prostatectomy versus open radical retropubic prostatectomy: early outcomes from a randomised controlled phase 3 study. Lancet 2016; 388: 1057-66

14.Kouba EJ, Wallen EM, Pruthi RS, et al. Gum chewing stimulates bowel motility in patients undergoing radical cystectomy with urinary diversion. Urology 2007; 70: 1053-6.

15.Maffezzini M, Campodonico F, Parodi D, et al. Current perioperative management of radical cystectomy with intestinal urinary reconstruction for muscle-invasive bladder cancer and reduction of the incidence of postoperative ileus. Surg Oncol 2008; 17: 41-8.

16.Menon M, Hemal AK. Vattikuti Institute prostatectomy: a technique of robotic radical prostatectomy: experience in more than 1000 cases. J Endourol 2004; 18: 611-9.

17.Dayton MT, Townsend CM, Beauchamp RD, et al. Sabiston Textbook of Surgery, The Biological Basis of Modern Surgical Practice, 17thed. New York: Elsevier Saunders; 2004.

18.Quah HM, Samad A, Neathey AJ, et al. Does gum chewing reduce postoperative ileus following open colectomy for left-sided colon and rectal cancer? A prospective randomized controlled trial. Colorectal Dis. 2006; 8: 64-70.

19.Wille-JP, Guenaga KF, Castro AA, et al: pre-operative mechanical bowel cleansing or not? an updated meta-analysis. Colorectal Dis.2005; 7: 304-310.

20.Matros $E$, Rocha $F$, Whang $E$, et al. Does gum chewing ameliorate postoperative ileus? Results of a prospective, randomized, placebo controlled trial. J Am Coll Surg. 2006; 202: 773-778.

21.Gustafsson UO, Scott MJ, Schwenk W, et al. Guidelines for perioperative care in elective colonic surgery: enhanced recovery after surgery (ERAS $\left({ }^{\circledR}\right)$ ) society recommendations. World J Surg 2013; 37: 259-84.

22.Nygren J, Thacker J, Carli F, et al. Guidelines for perioperative care in elective rectal / pelvic surgery: enhanced recovery after surgery (ERAS $\left({ }^{\oplus}\right)$ ) society recommendations. World J Surg 2013; 37: 285-305.

23.Senagore A. Pathogenesis and clinical and economic consequences of postoperative ileus. Clin Exp Gastroenterol 2010; 3: 87-9.

24.Saclarides TJ. Current choices good or bad for the proactive management of postoperative ileus: a surgeon's view. J Perianesthesia Nurs 2006; 21: 7-15. 
25. Asao T, Kuwano H, Nakamura J, et al. Gum chewing enhances early recovery from postoperative ileus after laparoscopic colectomy. J Am Coll Surg. 2002; 195: 30-32.

26.Stewart B, Woods RJ, Collopy RJ, et al. Early feeding after elective open colorectal resections: A prospective randomized trial. Aust NZ J Surg. 1998; 68: 125-128.

27.Ballantyne JC, Mao J. Opioid therapy for chronic pain. N Engl J Med. 2003; 349: 1943-1953. 